\title{
Operational policy for disposal of land-derived wastewater to the marine environment of South Africa
}

\author{
S Taljaard ${ }^{1 *}$, WAM Botes ${ }^{2}$, SHH Oelofse ${ }^{3}$ and P Viljoen ${ }^{4}$ \\ ${ }^{1}$ CSIR, PO Box 320, Stellenbosch 7599, South Africa \\ ${ }^{2}$ WAMTechnology cc, PO Box 195, Stellenbosch 7599, South Africa \\ ${ }^{3}$ CSIR, PO Box 395, Pretoria, 0001, South Africa (formerly Department of Water Affairs and Forestry) \\ ${ }^{4}$ Department of Water Affairs and Forestry, Private Bag X313, Pretoria 0001, South Africa
}

\begin{abstract}
In 1998, South Africa's National Water Act (Act 36 of 1998) was promulgated to give legal status to the White Paper on a National Water Policy (April 1997) and the Department of Water Affairs' (DWAF) water quality management policies and strategies, amongst others. To fulfil its legal obligation in terms of the management and control of land-derived wastewater discharges (classified as a water use under the National Water Act), DWAF adopted the operational policy for disposal of land-derived water containing waste to the marine environment of South Africa in July 2004 (the marine environment including estuaries, the surf zone and offshore waters) in July 2004; this policy incorporates relevant international and national principles, policies and legislation.

The operational policy outlines the Department's new thinking in relation to discharges to sea and consists of:

- A goal

- Basic Principles, providing the broad reference framework or direction of the policy

- Ground Rules, providing more specific rules, derived within the broader context of the Basic Principles

- Management Framework, providing a generic, structured approach within which to implement the policy.

This paper is to provide an overview on the Basic Principles and Ground Rules that were adopted under the operational policy.
\end{abstract}

Keywords: land-derived wastewater, marine, South Africa, disposal, operational policy

\section{Introduction}

In 1998, the National Water Act (Act 36 of 1998) (NWA) was promulgated in South Africa to give legal status to the White Paper on a National Water Policy for South Africa (April 1997) and the Department of Water Affairs and Forestry's (DWAF) water quality management policies and strategies, amongst others. To fulfil its legal obligation in terms of the management and control of land-derived wastewater discharges (classified as a water use under the NWA), DWAF adopted the Operational Policy for Disposal of Land-Derived Water Containing Waste to the Marine Environment of South Africa in July 2004 (the marine environment including estuaries, the surf zone and offshore marine waters) in July 2004 (RSA DWAF, 2004a-c). The policy incorporates relevant international and national principles, policies and legislation.

Oelofse et al. (2005) discussed the approach and methodology followed in the development of the operational policy, in alignment with DWAF's strategic view on the disposal of landderived wastewater. Their paper also discussed the major components of the operational policy (Fig. 1), namely:

- A Goal that is to achieve water quality that is 'fit for use' and that can maintain aquatic ecosystem health on a sustainable basis by protecting the country's water resources (including marine waters), in a manner allowing justifiable social and economic development. This will be achieved in accordance with the hierarchy of decision-making for water

\footnotetext{
* To whom all correspondence should be addressed.

잉 +27 21 8882494; fax: +27 21 882693;

e-mail: staljaar@,csir.co.za

Received 24 November 2005; accepted in revised form 7 August 2006.
}

quality management, namely Prevent waste; Minimise waste and Dispose responsibly'.

- Basic Principles, providing the broad reference framework or direction of the policy

- Ground Rules, providing more specific rules, derived within the broader context of the Basic Principles

- Management Framework, providing a generic, structured approach within which to implement the policy.

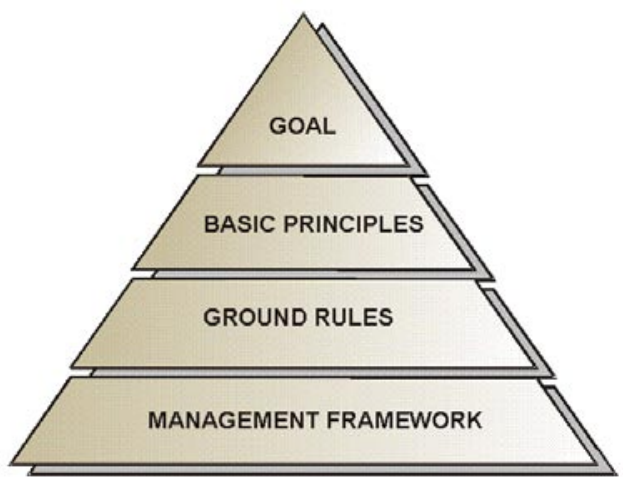

\section{Figure 1}

The structure of the operational policy for treatment and disposal of land-derived wastewater to the marine environment of South Africa (Oelofse et al., 2005)

This paper provides an overview of the Basic Principles and Ground Rules adopted as part of the operational policy. Note that this paper provides an overview only and it is strongly recommended that the original policy documentation be consulted for management purposes (DWAF, 2004a-c). An eco- 
system-scale approach to marine water quality management (similar to the Management Framework adopted as part of this policy) is discussed in a separate paper (Taljaard et al., 2006).

\section{The Basic Principles}

The Basic Principles of the operational policy provide the broad reference framework or direction within which Ground Rules for the disposal of land-derived wastewater to the marine environment were developed. These principles were distilled from the broader international and national legislative context (RSA DWAF, 2004c) pertaining to the disposal of land-derived wastewater to the marine environment. Five basic principles were adopted, namely:

- Pollution Prevention, Waste Minimisation and the Precautionary Approach, that is strongly supported in water quality management policy of DWAF.

- Receiving Water Quality Objectives Approach, which requires that the aquatic ecosystem, as well as other beneficial uses of water resources, ultimately determine the objectives to be met (rather than following a uniform effluent standard approach).

- Integrated Assessment Approach, adhering to the principles of Integrated Environmental Management and taking cognizance of concepts such as Strategic Environmental Assessment and Environmental Impact Assessment.

- Polluter Pays Principle, where the responsibility for environmental costs incurred for rehabilitation of environmental damage and the costs of preventive measures to reduce or prevent such damage is shifted to the impactors.

- Participatory Approach, that requires stakeholder participation, not only as part of the decision-making process (e.g. environmental impact assessment process and setting of common environmental quality objectives), but also through ongoing transparent and open communication on the status quo during design, construction and operational phases.

\section{The Ground Rules}

The Ground Rules of the operational policy provide more specific requirements that will be applied by Government when considering licence applications to dispose of land-derived wastewater to the marine environment. These were derived within the broader context of the Basic Principles (RSA DWAF, 2004a). For this operational policy, the Ground Rules were organised into specific themes (or topics) that are also aligned with the key components of the Management Framework (Taljaard et al., 2006). The rationale for the selection, as well as a summary of the Ground Rules, within each of these themes are discussed below.

\section{Legislative aspects}

The operational policy falls within the category of Best Practice Guidelines (Cloete and Wissink, 2000) and as a result it must be underpinned by legislation. In this case there are a number of legal (or statutory) requirements to be complied with which are captured in the Ground Rules as follows:

- Disposing of wastewater through a sea outfall must be licensed by the DWAF under the NWA which is subject to review every five (5) years

- Disposal of wastewater to the marine environment is subject to the Environmental Impact Assessment (EIA) Regulations under the National Environmental Management Act (Act
107 of 1998) (formerly under the Environmental Conservation Act [Act 73 of 1989])

- Discharge of wastewater to any area declared a Marine Protected Area is prohibited under the Marine Living Resources Act (Act 18 of 1998)

- Any land-derived wastewater discharge to the marine environment may be subject to a waste discharge charge (as made provision for under the NWA).

\section{Management institutions and administrative responsibilities}

Although DWAF is responsible for the overarching management and administration of the disposal of land-derived wastewater to the marine environment, a key element in the successful implementation of this operational policy is the establishment of local management institutions, representing all the role players in a designated area and which fulfil the role of 'local watchdogs' or 'custodians'. However, water service providers (operating wastewater treatment works) and industries that dispose wastewater to the marine environment still hold ultimate responsibility in terms of their individual licence conditions with DWAF.

Where multiple developments and activities occur in a specific area, it is usually extremely difficult and financially uneconomical to manage environmental issues in isolation because of, for example, potential cumulative or synergistic effect on the receiving marine environment. Collaboration is often best achieved through a joint local management institution. Although such institutions could be initiated from local level it is, however, crucial that these be coordinated from a national (or regional) level by the responsible government authorities, such as the Department of Environmental Affairs and Tourism (DEAT) and DWAF. that:

It was therefore important to stipulate, in the Ground Rules,

- DWAF will work in consultation with relevant local, provincial and national government departments (in particular DEAT), as well as local management institutions (such as pipeline or catchment forums) to ensure effective cooperative governance in the management of waste disposal to the marine environment of South Africa.

- Disposal of land-derived wastewater to the marine environment must be managed through a local management institution where representation must include government authorities (i.e. that hold jurisdiction), as well as non-government role players (e.g. industries, users of the marine environment and non-government organisations).

\section{Environmental quality objectives (including sensitive areas)}

The marine environment can be subdivided roughly into three zones, each having distinctly different physical processes that influence their ability to assimilate wastewater, although the overall functioning is still strongly interdependent. These are the offshore environment, the surf zone and estuaries.

The offshore environment (typically defined as the zone beyond the surf zone or breaker zone) extends over a large area and usually has strong, more uniform water circulation characteristics that allow for effective transport and dispersion. In contrast, the physical processes in the surf zone and estuaries are often very complex and highly variable and water exchange from these zones is also not very good. These zones are therefore considered as being ecologically sensitive with very little 
assimilative capacity for anthropogenic inputs, such as landderived wastewater. Estuaries are also sheltered water bodies in which circulation patterns depend largely on the river inflow and the state of the mouth. Water exchange therefore ranges from 'very good' when river inflow is high and water is continuously flushed from the system to 'limited' or 'no' water exchange when the mouth is closed. The latter is particularly relevant to South Africa, where more than $75 \%$ of its estuaries are temporarily closed off to the sea.

The high complexity in circulation patterns of the surf zone and estuaries largely reduces the accuracy with which transport and dispersion processes can be quantified, a key requirement in assessing the suitability of using the marine environment for the disposal of land-derived wastewater.

In the context of the above, although the offshore is considered to be a more appropriate environment for the disposal of wastewater, compared to the surf zone and estuaries, the suitability of a particular offshore environment must still be assessed on a site specific basis. The suitability of a particular offshore environment largely depends on factors such as:

- Circulation characteristics, for example, strong currents enhance the achievable initial dilution, whereas rapid transport of the plume reduces the degree of decay of microbiological organisms between the discharge location and relevant beneficial use areas.

- Stratification in the water column, for example, strong stratification (e.g. presence of a thermocline) results in the inhibition of a rising buoyant effluent plume and subsequent reduced initial dilution.

- Proximity of depositional areas, i.e. areas where wave and flow generated bed shear stresses (turbulence) are reduced, resulting in particulate material (and associated pollutants) being deposited onto sediments.

- Presence of offshore reefs and islands, as well as marine protected areas (declared under the Marine Living Resource Act [No. 18 of 1998]), which are also considered to be 'sensitive areas'.

- Risk of damage, for example shipping routes where the marine disposal structure could be damaged by dropping or dragging anchors.

Inappropriate disposal of wastewater (e.g. when treatment systems malfunction, usually during the holiday season from overloading) or even disposing of 'clean' freshwater (e.g. tertiary treated wastewater) to sensitive systems such as estuaries and the surf zone can have serious ripple effects, both ecologically and socio-economically. Historically, disposal to the marine environment around the South African coast (particularly discharges to estuaries and the surf zone) was allowed not necessarily on the grounds that it was the best environmental option. Economic considerations were more frequently the driving factor behind the decision rather than environmental or social considerations.

Based on the above, the following Ground Rules were stipulated in relation to sensitive areas:

- Disposal of municipal and industrial wastewater to estuaries will not be considered except in exceptional circumstances in which such inflows are required to improve or maintain the resource quality objectives or where the ecological functioning has been irreversibly modified, for example to support commercial harbours; in the latter case the resource quality objectives set for other beneficial uses (as discussed later) must be met as a minimum.
- Disposal of municipal and industrial wastewater to the surf zone should be avoided. Where legitimate motivation can be provided (e.g. in cases in which seawater used on land is returned to source), the environmental quality objectives determined for the study area (as discussed later) must be met as a minimum.

- Discharges of land-derived wastewater to the offshore marine waters through a marine outfall may be considered as an option provided that the suitability of the areas to accommodate such activities is properly assessed.

The receiving water quality objectives approach requires that the aquatic ecosystem of the water resource, as well as the requirements of the beneficial uses of that water resource, determine the objectives that need to be adhered to (rather than following a uniform effluent standard approach) and is widely used internationally.

Under the NWA estuaries are defined as water resources which require that a Classification, Reserve (water allocated to basic human needs, as well as that required by aquatic ecosystems) and Resource Quality Objectives (also referred to as environmental quality objectives) be determined for each system. The classification system, once developed, will therefore assign a management class (and associated resource quality objectives) to estuaries. However, marine waters (other than estuaries) are not included in the definition of a water resource in the NWA. Therefore the resource directed measures as specified in the NWA currently do not apply to such marine waters.

To assist in setting environmental quality objectives for marine water resources, the South African Water Quality Guidelines for Coastal Marine Waters, was published by DWAF in 1995 (RSA DWAF, 1995b). The South African guidelines provide recommended target values (not standards) for a range of substances, but are not exhaustive. Therefore, in setting sitespecific environmental quality objectives, it may be necessary to consult additional information obtained from published literature, best available international guidelines (e.g. ANZECC 2000a; US-EPA, 2002), as well as site-specific data.

The above rationale led to the following Ground Rules related to environmental quality objectives:

- Site-specific environmental quality objectives for the marine environment must take into account the South African Water Quality Guidelines for Coastal Marine Waters or any future updates thereof

- Where, in exceptional circumstances, a discharge to an estuary is considered, resource quality objectives must be determined according to the methodology for estuaries developed by the Directorate: Resource Directed Measures or any future updates thereof

- Environmental quality objectives must be met within the area beyond the initial mixing zone (when disposing of wastewater to the offshore marine environment, the initial mixing zone is typically defined as the area in the water column in which the initial dilution process takes place whereby 'clean' seawater is entrained during the rise of the buoyant plume).

\section{Activities and associated waste loads (municipal, industrial \& diffuse wastewaters)}

Being a semi-arid country, a key concern in South Africa is future water demand. A major constraint in the management of municipal wastewater, including that of towns and cities along 
the South African coast, is that the disposal of land-derived wastewater is currently not addressed within the context of future water demand and supply. Also, instead of planning the collection, treatment and disposal of wastewater in, for example, an entire metropolitan area in a holistic manner, wastewater treatment works (WWTW) are typically designed and operated in a fragmented manner. As a result, the wastewater discharges from these WWTW often have cumulative negative impacts on the receiving environment which were not taken into account in either the design or operations of such WWTW.

It is therefore crucial that wastewater disposal be managed within a 'Master Plan' for water. For example, where re-use of wastewater will be essential to meet future water demand, wastewater treatment and disposal systems must accommodate such requirements in their design criteria, even though the ultimate implementation of such criteria may be incremental. In terms of achieving this 'Master Plan' concept, the Water Services Development Plans that need to be prepared by a service provider (e.g. local municipality) under the Water Services Act (Act 108 of 1997), as part of Integrated Development Plans (in terms of the Local Government Transition Act [Act 209 of 1993]), can be extended to also include the disposal of land-derived wastewater.

The design of a marine disposal practice depends largely on the quantity and quality of the effluent. These, in turn, depend on the service population (including industrial wastewater discharges into WWTW) that are effectively linked to the collecting system and the degree of treatment of the wastewater prior to discharge. Although non-sewered treatment such as French drains and septic tanks, may be acceptable options for smaller communities, these are usually not acceptable for larger service populations. The risk of impact on water resources, associated with spillages and seepage, increases markedly with the increase in the number and density of nonsewered systems. Internationally it has become common practice to provide a collecting system to communities with a service population greater than about 2000 , including coastal communities (RSA DWAF, 2004c). South African policy in this regard is dealt with in documents such as Strategic Framework for Water Services (RSA DWAF, 2003a) and Managing the Water Quality Effects of Settlements (RSA DWAF, 1999a; RSA DWAF, 2002).

With regard to the level of treatment of municipal wastewater prior to discharge, the main objective applied internationally is to reduce waste loads, particularly those of suspended solids and biochemical oxygen demand. Municipal wastewater has characteristic loads of these two substances that are easy to measure and, by reducing these, it is also possible to markedly decrease the loads of other potentially harmful substances, e.g. nutrients and toxins such as trace metals. Most countries require primary treatment as a minimum for offshore marine outfalls.

In the United States, Australia and the European Community this minimum rule applies only for service populations of between 50000 and 150000 . For larger service populations these countries require at least secondary treatment, in many instances including disinfection (RSA DWAF 2004c). As an incentive to reduce waste loads in municipal wastewater, both the United States and Australia have introduced a charge system, similar to the Waste Discharge Charge System being developed by DWAF (RSA DWAF, 2003b).

For this operational policy the following Ground Rules were therefore stipulated in relation of municipal wastewater discharges:
- Marine disposal of land-derived municipal wastewater (particularly freshwater) will only be considered where it has been evaluated in terms of the Water Services Development Plan for a particular municipal area

- Municipal WWTW receiving industrial wastewater (also referred to as trade effluent) will be required to prepare Industrial wastewater management plans (as part of the 'Master Plan'). It is also the responsibility of the service provider or local authority to investigate possible synergistic and/or cumulative effects which may occur as a result of the interaction between different (industrial) wastewater inputs.

- Primary treatment will be required as a minimum for disposal of municipal wastewater to the offshore marine environment. As a minimum, secondary treatment with disinfection will be required for disposal to the surf zone and estuaries.

- The disposal of sludge arising from wastewater treatment facilities (e.g. primary, secondary and tertiary) must be in accordance with the Minimum Requirements for Waste Disposal by Landfill (RSA DWAF, 1998) and the 'Sludge Guidelines' (RSA DWAF, 1997; RSA DWAF, 2002a) of DWAF or any future updates of such policies or guidelines.

International policies regarding the disposal of industrial wastewater to the environment (including the marine environment) are extensive and follow different approaches (RSA DWAF, 2004c). One approach is to identify specific industrial installations that are required to obtain authorisation to operate as is the case in the European Community where the Directive on Integrated Pollution Prevention and Control (96/61/ EC) provides a list of industrial installations and a set of common rules on permits, based on the concept of Best Available Techniques. The Directive also identifies specific aspects that need to be taken into account when determining best available techniques. Another approach towards eliminating or minimising wastewater from industrial installations is to regulate the operations and processes for specific industries, based on the concept of Best Available Techniques. Canada, for example, sets specific standards, guidelines and an environmental code of practice for numerous industrial activities under the Canadian Environmental Protection Act of 1999. With regard to disposal of industrial wastewater into WWTW, most countries require that pre-treatment be applied so as to prevent damage to equipment, that the treatment or re-use of sludge is not impeded and that there will be no adverse effect on the marine environment.

The NWA of South Africa states that 'disposing in any manner of water which contains waste from, or which has been heated in, any industrial or power generation process' requires a licence from DWAF (this includes stormwater runoff from industrial installations). South Africa's legislation, therefore, does not distinguish between different types of industries but rather subjects all industries to applying for authorisation for wastewater disposal, including disposal to the marine environment.

Taking into account the above, the following Ground Rules were specified for industrial wastewater discharges:

- The following is classified as 'industrial wastewater', requiring a licence for disposal to the marine environment under the NWA: Water used in an industrial process on land; contaminated (or polluted) stormwater runoff originating from an industrial premises on land; freshwater or seawater used as cooling water on land and seawater used in an industrial 
process on land, e.g. seafood processing, coastal mining activities and return flows from oceanaria.

- An industry, discharging wastewater to a municipal WWTW or directly to the marine environment (or applying for a licence to do so), will be required to provide a detailed description of the waste stream in terms of both volume (quantity) and quality (i.e. listing all substances present and their concentrations and loads).

- Industrial wastewater discharged to a municipal WWTW disposing to the marine environment will be subject to appropriate pre-treatment. It is the responsibility of the local authority operating the WWTW to ensure compliance in this regard.

- Wastewater containing radioactive substances is primarily governed by the Department of Minerals and Energy and must comply with policy developed in this regard.

Diffuse wastewater sources include urban stormwater runoff, agricultural and mining return flows, as well as contaminated groundwater seepage (these can either directly discharge into the marine environment or indirectly through river inflow).

In the assessment of wastewater disposal to the marine environment, diffuse wastewater inputs must be taken into account. Although there are means of calculating and measuring the volumes and composition of diffuse wastewater inputs, controlling such properties, once the wastewater reaches the marine environment (or any other water resource), is extremely difficult. Such activities, therefore, are best managed and controlled at source, i.e. the point of origin. Operational policies for the management and control of diffuse wastewater at source are not specific to the marine environment, but apply to any water resources, including rivers, groundwater and wetlands. Diffuse wastewater sources are therefore best dealt with on a catchment level, rather than per individual water resource component.

Regarding diffuse wastewater discharges, urban stormwater runoff is one of the most important concerns in coastal metropolitan areas. The vast volumes and runoff characteristics of urban stormwater make treatment prior to disposal extremely difficult and expensive. Mitigating treatment at source, i.e. preventing pollution rather than treatment, is usually a more cost-effective route to follow in the case of these non-point sources of pollution. An approach that appears to be effective in this regard is the establishment of Stormwater Management Programmes, as implemented for example in Scotland and the United States of America (SEPA, 2001; United States, Los Angeles County, 1996; United States, Virginia, City of Norfolk, 2004).

Taking the above into account, operational policy for the management and control of urban stormwater needs to be set at catchment level, as such policies are not specific to stormwater runoff to the marine environment, but should apply to runoff to any water resource, including rivers, groundwater and wetlands. Therefore, operational policy pertaining to stormwater is not specifically addressed as part of this policy. The Ground Rule merely states that:

- Diffuse land-derived wastewater (such as urban stormwater runoff, agricultural return flows and contaminated groundwater seepage) discharged into the marine environment should not have any negative impact on the receiving environment, i.e. the environmental quality objectives must be met.

It is, however, proposed that a national operational policy for the management and control of urban stormwater be developed for
South Africa, taking into account relevant international development, as well as existing national initiatives such as:

- The Framework for Implementing Non-Point Source Management under the National Water Act (RSA DWAF, 1999a), stating that non-point source management is largely focused on land use, rather than water use, and should be conducted within the context of catchment management. The document proposes that a national non-point source strategy be put forward for South Africa as part of the national water resource strategy.

- Guidelines for Human Settlement Planning and Design - The Red Book (CSIR, 2001), also strongly reflect international trends in terms of stormwater management. For example, the Stormwater Management Master Drainage Plans dealt with in detail in this manual are strongly aligned with the Stormwater Management Programmes applied in the United States. The Red Book also stresses that such plans be contemplated on a catchment-wide basis, irrespective of urban and other man-made boundaries.

- Managing the Water Quality Effects of Settlements (RSA DWAF, 1999b, 2002c) that provides DWAF's strategy for managing waste streams from dense settlements, including the control and management of stormwater that should also to be taken into account in future operational policy development for urban stormwater runoff.

- Towards a Strategy for a Waste Discharge Charge System (RSA DWAF 2003b) which also includes charges for diffuse sources of wastewater, which should also be taken into account in the development of an operational policy for urban stormwater runoff for South Africa.

\section{Scientific and engineering assessment studies}

The marine environment functions as an ecosystem with no clear boundaries between its different components, namely estuaries, surf zone and offshore waters. It is therefore important that, where the disposal of land-derived wastewater to the marine environment is considered, the interaction between these different components be taken into account. Also of crucial importance is the consideration of other waste inputs and anthropogenic activities in the area to ensure that synergistic and/or cumulative interactions are addressed.

The impact of any wastewater discharge depends on the quantity and quality of the wastewater, as well as prevailing physical and chemical oceanographic conditions of the receiving environment. Oceanographic conditions of the marine waters are highly variable, both spatially and temporally, and are determined by factors such as the bathymetry of the seabed, currents, winds, tides, waves and the ambient water and sediment biogeochemistry. In order to set design criteria for a marine disposal system, it is necessary to predict the dilution, transport and fate of substances contained in the wastewater (and subsequent compliance to environmental quality objectives), taking into account site-specific oceanographic conditions. It is also important to consider other waste inputs to the area, both from point and diffuse sources (which may also include non-land derived sources such as inputs from shipping activities). Such predictions and assessments are normally made with some form of predictive modelling tool.

Internationally, it has become a requirement to use numerical modelling techniques in the design and assessment of marine disposal systems (SEPA, 2001; WRc, 1990 Not listed; US-EPA, 1994; Gunnerson, 1988). Models vary greatly in type and complexity and it is therefore essential that the model chosen be appropriate to the situation in which it is utilised. It is also 
important that the model be properly calibrated and validated in order to ensure that the model output is reliable and accurate.

A marine disposal system is a controllable mechanism of which the design is such that the impact on the environment can be manipulated through the degree of pre-treatment, flow rates (controlled by either a pressure or gravity head), the discharge depth and distance from specific beneficial use areas (determined by pipeline length and bathymetry) and dilution (diffuser design).

Specific Ground Rules stipulated in terms of scientific and engineering assessment studies are as follows:

- A licence application for the disposal of land-derived wastewater to the marine environment will only be considered where a holistic assessment process has been followed, that investigated potential impacts in the receiving environment both in the near and far field and that took into account other anthropogenic activities and waste inputs to address possible synergistic and/or cumulative effects.

- A licence application for the disposal of land-derived wastewater to the marine environment will only be considered where a discharge system is designed, constructed and operated in accordance with recognised scientific, hydraulic and structural guidelines in order to meet environmental quality objectives.

- Recognised numerical modelling techniques must be applied in the scientific and engineering assessment and design of a marine disposal system, as and where considered appropriate, according to recognised scientific and engineering guidelines.

- A precautionary approach must be followed in the assessment and design of any marine disposal system in which the temporal and spatial coverage and accuracy of physical and chemical oceanographic data do not adequately describe site-specific conditions.

\section{Monitoring and contingency plans}

Chapter 14 of the NWA clearly states that:

Monitoring, recording, assessing and disseminating information on water resources is critically important for achieving the objects of the Act. Part 1 of this Chapter places a duty on the Minister, as soon as it is practicable to do so, to establish national monitoring systems. The purpose of the systems will be to facilitate the continued and co-ordinated monitoring of various aspects of water resources by collecting relevant information and data, through established procedures and mechanisms, from a variety of sources including organs of state, water management institutions and water users.

Internationally, it is also recognised that monitoring and assessment are key requirements for effective control and management, including that of land-derived wastewater discharges to the marine environment (WRc, 1990; NZWERF, 2002; ANZECC 2000b; US-EPA, 2003).

Ground Rules pertaining to long-term monitoring and contingency planning are as follows:

- Any authority or industry responsible for the operation and management of a marine disposal system will be subject to the implementation of a monitoring programme

- Authorities operating WWTW that receive industrial wastewater (also referred to as trade effluents) must ensure that monitoring programmes are implemented to record the individual flow and composition of such wastewater inputs prior to entering the wastewater reticulation system, as part of their industrial wastewater management plan

- Any authority or industry responsible for the operation and management of a marine disposal system will be required to prepare contingency plans pertaining to maintenance shut downs, failure in operations or disasters

- Any authority or industry responsible for the operation and management of a marine disposal system will be required to provide DWAF with a regular evaluation of the performance of the system

- Where performance evaluations indicate non-compliance with the predetermined specifications (including the environmental quality objectives), the responsible authority or industry will be required to propose mitigating actions to ensure compliance (e.g. rehabilitation or alternative treatment options)

- Decommissioning of a marine disposal structure must be addressed in the planning stages as part of the EIA process, supporting the cradle-to-grave principle.

\section{Concluding remarks}

This operational policy was developed in consultation with key stakeholders including local, provincial and national government, non-government organisations, industry as well as scientific and technical experts. It was also subject to national and international peer review (RSA DWAF, 2004c).

In general, the operational policy was well-received by key stakeholders, although there were some concerns raised on matters such as the minimum treatment of municipal wastewater being too strict for a developing country. Nevertheless, on consensus, the Project Steering Committee decided to adopt international best practice and therefore the treatment requirements were not relaxed as had been proposed.

The next phase is the implementation where, for example, the regional offices of DWAF and DEAT will play a key role. The policy will also be subjected to regular review, supporting the principle of adaptive management. For example, the draft Policy on the Resource Directed Management of Water Quality developed by DWAF in 2005 (RSA DWAF, 2005) should be considered in future revisions of this operational policy.

\section{References}

AUSTRALIA AND NEW ZEALAND ENVIRONMENT AND CONSERVATION COUNCIL (ANZECC) (2000a) Australian and New Zealand Guidelines for Fresh and Marine Water Quality. National Water Quality Management Strategy No. 4. Canberra, Australia. ISBN 0957824505.

AUSTRALIA AND NEW ZEALAND ENVIRONMENT AND CONSERVATION COUNCIL (ANZECC) (2000b) Australian Guidelines for Water Quality Monitoring and Reporting. National Water Quality Management Strategy No. 7. Canberra, Australia. ISBN 0642195625.

CLOETE F and WISSINK H (eds.) (2000) Improving Public Policy. Van Schaik, Pretoria. 316 pp.

CSIR (2001) Guidelines for Human Settlement Planning and Design The Red Book. CSIR Report BOU/E2001. Pretoria, South Africa.

GUNNERSON CG (ed.) (1988) Waste water management in coastal cities: The ocean disposal option. World Bank Technical Paper No. WTP77, Washington D.C., USA ISBN 0-8213-0989-7.

NEW ZEALAND WATER ENVIRONMENT RESEARCH FOUNDATION (NZWERF) (2002) New Zealand Municipal Wastewater Monitoring Guidelines. In: Ray D (ed.) Published by the New Zealand Water Environment Foundation, Wellington. ISBN 1-87713440-6. 
OELOFSE SHH, VILJOEN P, TALJAARD S and BOTES WAM (2005) Discharge of water containing waste emanating from land to the marine environment: A water quality management perspective. Water SA 30 (5 - Special edition) 56-60.

REPUBLIC OF SOUTH AFRICA DEPARTMENT OF WATER AFFAIRS AND FORESTRY (RSA DWAF) (1991) Water Quality Management Policies and Strategies in the RSA. DWAF, Pretoria, South Africa.

REPUBLIC OF SOUTH AFRICA DEPARTMENT OF WATER AFFAIRS AND FORESTRY (RSA DWAF) (1995a) South African Water Quality Management Series. Procedures to Assess Effluent Discharge Impacts. ( $1^{\text {st }}$ edn.) WRC Report TT 64/94. Water Research Commission, Pretoria, South Africa.

REPUBLIC OF SOUTH AFRICA DEPARTMENT OF WATER AFFAIRS AND FORESTRY (RSA DWAF) (1995b) South African Water Quality Guidelines for Coastal Marine Waters. Vol. 1: Natural Environment. Vol. 2: Recreation. Vol. 3: Industrial Use. Vol. 4: Mariculture. DWAF, Pretoria, South Africa.

REPUBLIC OF SOUTH AFRICA DEPARTMENT OF AGRICULTURE, DEPARTMENT OF HEALTH, DEPARTMENT OF WATER AFFAIRS AND FORESTRY, WATER INSTITUTE OF SOUTHERN AFRICA, WATER RESEARCH COMMISSION. (RSA DWAF) (1997) Permissible Utilisation and Disposal of Sewage Sludge (Edn. 1) WRC Report No. TT 85/97. Water Research Commission, Pretoria, South Africa.

REPUBLIC OF SOUTH AFRICA DEPARTMENT OF WATER AFFAIRS AND FORESTRY (RSA DWAF) (1998) Waste Management Series. Minimum Requirements for Waste Disposal by Landfill ( $2^{\text {nd }}$ edn.). DWAF, Pretoria, South Africa. ISBN 0620-22993-4.

REPUBLIC OF SOUTH AFRICA DEPARTMENT OF WATER AFFAIRS AND FORESTRY (RSA DWAF) (1999a) A Framework for Implementing Non-point Source Management under the National Water Act. DWAF Report No. WQP 0.1. WRC Report No. TT 115/99. Water Research Commission, Pretoria, South Africa.

REPUBLIC OF SOUTH AFRICA DEPARTMENT OF WATER AFFAIRS AND FORESTRY (RSA DWAF) (1999b) Managing the Water Quality Effects of Settlements (Edition 1). The National Strategy (Policy Document U 1.1), Guidelines for Implementation (Operational Guideline U 1.2), A Guide to Problem Analysis (Operational Guideline U 1.3), Information Booklet to Support Community Efforts to Minimise Water Pollution from their Settlements - Working Towards a Clean and Healthy Community.

REPUBLIC OF SOUTH AFRICA: DEPARTMENT OF AGRICULTURE, DEPARTMENT OF HEALTH, DEPARTMENT OF WATER AFFAIRS AND FORESTRY, WATER INSTITUTE OF SOUTHERN AFRICA, WATER RESEARCH COMMISSION (RSA DWAF) (2002a) Addendum No 1 to Edition 1 (1997) of Permissible Utilisation and Disposal of Sewage Sludge. WRC Report No TT 154/01. Water Research Commission, Pretoria, South Africa.

REPUBLIC OF SOUTH AFRICA DEPARTMENT OF WATER AFFAIRS AND FORESTRY (RSA DWAF) (2002b) Managing the Water Quality Effects of Settlements. Directorate Water Quality Management, Pretoria.

REPUBLIC OF SOUTH AFRICA DEPARTMENT OF WATER AFFAIRS AND FORESTRY (RSA DWAF) (2003a) Strategic Framework for Water Services. September 2003. Pretoria.

REPUBLIC OF SOUTH AFRICA DEPARTMENT OF WATER AFFAIRS AND FORESTRY (RSA DWAF) (2003b) Towards a strategy for a waste discharge charge system. Water Quality Management Series. Sub-series No. MS 11. First Edition. 30 September 2003. Pretoria.
REPUBLIC OF SOUTH AFRICA DEPARTMENT OF WATER AFFAIRS AND FORESTRY (RSA DWAF) (2004a) Water Quality Management Series Sub-Series No. MS 13.2. Operational Policy for the Disposal of Land-Derived Water Containing Waste to the Marine Environment of South Africa. Edition 1. DWAF, Pretoria.

REPUBLIC OF SOUTH AFRICA DEPARTMENT OF WATER AFFAIRS AND FORESTRY (RSA DWAF) (2004b) Water Quality Management Series Sub-Series No. MS 13.3. Operational Policy for the Disposal of Land-Derived Water Containing Waste to the Marine Environment of South Africa - Guidance on Implementation. Edition 1. DWAF, Pretoria.

REPUBLIC OF SOUTH AFRICA DEPARTMENT OF WATER AFFAIRS AND FORESTRY (RSA DWAF) (2004c) Water Quality Management Series Sub-Series No. MS 13.4. Operational Policy for the Disposal of Land-Derived Water Containing Waste to the Marine Environment of South Africa - Appendices. Edition 1. DWAF, Pretoria

REPUBLIC OF SOUTH AFRICA DEPARTMENT OF WATER AFFAIRS AND FORESTRY (RSA DWAF) (2004d) Methodology for the Determination of the Preliminary Ecological Reserve for Estuaries. Version 2. DWAF, Pretoria, South Africa.

REPUBLIC OF SOUTH AFRICA DEPARTMENT OF WATER AFFAIRS AND FORESTRY (RSA DWAF) (2005) Draft Policy on the Resource Directed Management of Water Quality. Water Resource Planning Systems. Sub-Series No WQP 1.5.1. Version 2. Pretoria.

TALJAARD S, MONTEIRO P M S and BOTES WAM (2006) A structured ecosystem-scale approach to marine water quality management. Water SA 32 (4) 535-542.

SCOTTISH ENVIRONMENTAL PROTECTION AGENCY (SEPA) (2001) Regulations of Urban Drainage (Policy No. 15 [Version 2]). SEPA ENV12-E01/Policy www.sepa.org.uk/policies/index.htm. Accessed on 18 Sep 2006.

UNITED STATES ENVIRONMENTAL PROTECTION AGENCY (US-EPA) (1994) Amended Section 301(h) Technical support document, Office of Water. EPA842-B-94-007. Www.epa.gov/owow oceans/regulatory/sec301tech . Accessed on 18 Sep 2006.

ENVIRONMENTAL PROTECTION AGENCY (US-EPA) (2002) Water Quality Criteria www.epa.gov/waterscience/criteria/. Accessed on 18 Sep 2006.

UNITED STATES ENVIRONMENTAL PROTECTION AGENCY (US-EPA) (2003) Elements of a State water monitoring and assessment programme. Assessment and Watershed Protection Division. Office of Wetlands, Oceans and Watershed. United States Environmental Protection Agency. EPA 841-B-03-003. (www.epa.gov owow/monitoring/repguid.htm. Accessed on 18 Sep 2006.

UNITED STATES ENVIRONMENTAL PROTECTION AGENCY (US-EPA) (2004) National Pollutant Discharge Elimination System (NPDES) - Storm water permitting www.epa.gov/region08/water stormwater/index.htm . Accessed on 18 Sep 2006

UNITED STATES, LOS ANGELES COUNTY (1996) Order for Waste Discharge Requirements for Municipal Stormwater and Urban Runoff Discharges within the County of Los Angeles (http://lacounty. info/environment.htm). Accessed on 18 Sep 2006.

UNITED STATES, VIRGINIA, CITY OF NORFOLK (2004) Stormwater fees www.norfolk.gov/publicworks/stormwater.asp\#fees. Accessed on 18 Sep 2006.

WATER RESEARCH CENTRE (WRc) (1990) Design Guide for Marine Treatment Schemes. Volume I: Introduction, Volume II: Environmental Design and Data Collection, Volume III: Materials, Construction and Structural Design and Volume IV: Operations and Maintenance and Cost Functions. Report No. UM 1009. Swindon, UK. 